\title{
Intranasal Administration of Nitroglycerine in the Prevention of Hyperten- sion during Direct Laryngoscopy and Tracheal Intubation
}

\author{
Said A. Latief
}

\begin{abstract}
Abstrak
Nitrogliserin secara intranasal telah diberikan kepada 35 pasien dewasa satu menit sebelum induksi anestesia. Kelompok kontrol juga terdiri dari 35 pasien dewasa, mendapat obat standar $1.5 \mathrm{mg} / \mathrm{kg}$ berat badan lidokain intravena. Tekanan darah arteri dan laju nadi direkain sebelum, selama dan sesudah induksi anestesia dan pada menit ke - 0, 1, 2, 3, 5, 7 dan 10 setelah intubasi trakea. Perubahan-perubahan tekanan darah sistolik secara klinis tidak bermakna pada kedua kelompok. Laju nadi naik pada kelompok A dan menurun pada kelompok $B$, secara klinis tak bermakna. Nitrogliserin cukup efektif, aman dan mudah diberikan secara intra-nasal untuk mencegah terjadinya lonjakan hipertensi akibat laringoskopi langsung dan intubasi trakea.
\end{abstract}

\begin{abstract}
Intranasal nitroglycerine was administered to 35 adult patients, one minute before the induction of anesthesia. The controlgroup, also consisting of 35 adult patients, received the standard agent of $1.5 \mathrm{mg} / \mathrm{kg}$ body weight of lidocaine intravenously. Arterial blood pressure and heart rate were recorded before, during, and after the induction of anesthesia and at minute 0, 1, 2, 3, 5, 7 and 10 after tracheal intubation. Changes in systolic blood pressure were not clinically significant in both groups. There was an increase in heart rate in group $A$ and a decrease in group $B$; both were not clinically significant. Intranasally administered nitroglycerine was found to be an effective, safe, and simple method in attenuating the hypertensive response to direct laryngoscopy and tracheal intubation.
\end{abstract}

Keywords : Anesthetic, laryngoscopy-intubation, nitroglycerine

\section{INTRODUCTION}

During light general anesthesia, direct laryngoscopy and tracheal intubation uncomplicated by hypoxia, hypercapnia, or cough, can stimulate the trigeminal nerves or reflex sympathetic discharge causing an increase in heart rate, arterial blood pressure and dysrhythmia in up to $90 \%$ of patients. ${ }^{1,2,3}$ This changes are not of great clinical significance in healthy patients, but will likely become exaggerate in subjects with changes in the blood gases or hypertension., 4

Pharmacological attempts to attenuates blood pressure and heart rate elevations include: topical laryngeal analgesia with $4 \%$ lidocaine,${ }^{3,6,7} 1.5 \mathrm{mg} / \mathrm{kg}$ body weight lidocaine, ${ }^{8} 0.4 \mathrm{mg} / \mathrm{kg}$ body weight hydralazine, ${ }^{9} 150 \mu \mathrm{g} / \mathrm{kg}$ body weight droperidol, ${ }^{10}$ $0.01 \mathrm{mg} / \mathrm{kg}$ body weight propranolol, ${ }^{11}$ and $1-2 \mu \mathrm{g} / \mathrm{kg}$ body weight/of sodium nitroprusside ${ }^{12}$ by intravenous routes, and $10 \mathrm{mg}$ sublingual nifedipine. ${ }^{13}$

The purpose of this study was to investigate the effect of intranasal nitroglycerine on hypertension during direct laryngoscopy and tracheal intubation.

\section{MATERIALS AND METHODS}

Seventy male and female patients admitted to the hospital for elective surgery, with age ranging from 18 - 40 years and body weight between $40-65 \mathrm{~kg}$, were randomly divided into 2 groups. In this double blind study, group A received intranasal nitroglycerine (NTG) while group B received intravenous lidocaine (LC) 1 minute prior to the induction of anesthesia (Table 1). After full explanation of the purpose of this study, informed consent was obtained from all

Department of Anesthesiology, Faculty of Medicine, University of Indonesia/Dr. Cipto Mangunkusumo Hospital, Jakarta, Indonesia. 
patients. All patients were given a physical examination on the day preceeding surgery. They were found to be in good physical health, ASA I, with no nasal abnormalities. ECG, arterial blood pressure, and heart rate were normal (Table 2). Both groups were comparable in terms of age, weight, and physical status $(p>0.05)$.

Table 1. Age ( $y r s$ ) and weight ( $\mathrm{kg}$ ) of patients in groups A and $B$.

\begin{tabular}{lcc}
\hline & $\begin{array}{c}\text { Group A } \\
(\text { Mean } \pm \text { SD) }\end{array}$ & $\begin{array}{c}\text { Group B } \\
\text { (Mean } \pm \text { SD) }\end{array}$ \\
\hline Age & $30.1 \pm 7.67$ & $30.74 \pm 7.04$ \\
\hline Weight & $49.06 \pm 6.09$ & $48.91 \pm 8.17$ \\
\hline $\mathrm{N}$ & 35 & 35 \\
\hline
\end{tabular}

Table 2. Blood pressure and heart rate per minute of patients in groups $\mathrm{A}$ and $\mathrm{B}$ before induction of anesthesia.

\begin{tabular}{lcc}
\hline & $\begin{array}{c}\text { Group A } \\
\text { Mean } \pm \text { SD) }\end{array}$ & $\begin{array}{c}\text { Group B } \\
(\text { Mean } \pm \text { SD) }\end{array}$ \\
\hline Systolic & $124.34 \pm 10.10$ & $124.94 \pm 10.00$ \\
\hline Diastolic & $77.77 \pm 10.22$ & $75.94 \pm 11.36$ \\
\hline Mean AP & $98.77 \pm 12.75$ & $96.69 \pm 12.78$ \\
\hline Heart rate & $90.54 \pm 09.10$ & $90.83 \pm 08.10$ \\
\hline
\end{tabular}

Premedication consisted of only $20 \mathrm{mg}$ diazepam (Valium, Roche) orally, 90 minutes before induction of anesthesia. No anticholinergic, neuroleptic or narcotic analgetic drugs were given. On arrival in the operating theatre, blood pressure and heart rate were recorded, after a period of 5 minutes rest. Five minutes after oxygenation with $\mathrm{O}_{2} 100 \%$ via a facemask, the patients in group A received $2 \mathrm{ml}(0.6 \mathrm{mg} / \mathrm{kg})$ of NTG solution, in different concentrations, which was instilled intranasally using a glass syringe and a 16gauge teflon i.v. canulla. Group B received $1.5 \mathrm{mg} / \mathrm{kg}$ body weight lidocaine intravenously. One minute after the administration of NTG or lidocaine, anesthesia was induced with $6 \mathrm{mg} / \mathrm{kg}$ body weight of thiopentone followed by $0.1 \mathrm{mg} / \mathrm{kg}$ body weight of vecuronium (Norcuron, Organon) to facilitate endotracheal intubation. The NTG solution can be readily prepared by crushing NTG tablets or opening capsules (5-8 tablets or capsules of Nitromack) in normal saline solution, just before the induction of anesthesia.

The patient was withdrawn from the study when difficulties in intubation occurred or intubation was not accomplished at the first attempt. In the absence of concurrent stimulation produced by surgery, blood pressure and heart rate were recorded as soon as the tracheal tube cuff was inflated (minute 0), again at minute 1, 2, 3, 5, 7, and 10 after intubation. Following tracheal intubation, ventilation of the lungs was controlled with $33.3 \% \quad \mathrm{O}_{2}$ in $\mathrm{N}_{2} \mathrm{O}(1: 2)$ for 10 minute. No analgesic drugs or inhalation anesthetics which might have affect on the hypotensive effect of NTG or lidocaine were given for the 10 minutes following tracheal intubation. Student's $t$ test was used for analysis within the groups.

\section{RESULTS}

Systolic blood pressure of patients in group A decreased gradually from minute 0 to minute 10 , after intubation. Although not clinically significant, the difference was statistically significant $(p<0.05)$. In the group $\mathrm{B}$, systolic blood pressure was increased in minute 0 and 5 , but was decreased in minute $1,2,3,7$ and 10. The difference was also statistically significant $(p<0.05)$ but was not clinically significant (Table 3). Intubation time of the group A $(8.69 \pm 1.26)$ seconds and group B $(8.46 \pm 1.31)$ seconds $(p>0.05)$ were comparable.

Table 3. Systolic blood pressure of groups A and B during and after intubation.

\begin{tabular}{lccr}
\hline & $\begin{array}{c}\text { Group A } \\
(\text { Mean } \pm \text { SD) }\end{array}$ & $\begin{array}{c}\text { Group B } \\
(\text { Mean } \pm \text { SD) }\end{array}$ \\
\hline Before induction & $124.34 \pm 10.10$ & $124.94 \pm 10.10$ \\
Minute $\quad 0$ & $121.97 \pm 11.32$ & $127.97 \pm 11.87$ \\
Minute 1 & $120.06 \pm 10.95$ & $96.43 \pm 11.42$ \\
Minute 2 & $117.23 \pm 11.98$ & $93.29 \pm 07.62$ \\
Minute 3 & $113.83 \pm 12.05$ & $100.40 \pm 12.48$ \\
Minute 5 & $113.34 \pm 10.63$ & $125.74 \pm 09.23$ \\
Minute 7 & $110.66 \pm 11.09$ & $94.43 \pm 10.19$ \\
Minute 10 & $109.86 \pm 10.19$ & $92.43 \pm 07.13$ \\
\hline
\end{tabular}

The mean arterial pressure (MAP) of patients in group A decreased from minute 0 to minute 10 . In group B, it was decreased at minute $0,1,3,5$ and 7 , but was increased in minute 2 and 10. Although not clinically significant, the changes in both groups were statistically significant (Table 4 ). 
Table 4. Mean arterial pressure of groups A and B during and after tracheal intubation

\begin{tabular}{lcr}
\hline \multicolumn{1}{c}{ Time } & $\begin{array}{c}\text { Group A } \\
(\text { Mean } \pm \text { SD) }\end{array}$ & \multicolumn{1}{c}{$\begin{array}{c}\text { Group B } \\
(\text { Mean } \pm \text { SD) }\end{array}$} \\
\hline Before Induction & $98.77 \pm 12.75$ & $96.69 \pm 12.78$ \\
Minute 0 & $97.29 \pm 13.00$ & $88.57 \pm 08.06$ \\
Minute 1 & $93.34 \pm 11.66$ & $94.49 \pm 10.19$ \\
Minute 2 & $91.83 \pm 10.42$ & $114.63 \pm 11.36$ \\
Minute 3 & $90.14 \pm 12.65$ & $70.31 \pm 11.65$ \\
Minute 5 & $89.43 \pm 13.86$ & $87.31 \pm 08.35$ \\
Minute 7 & $86.91 \pm 13.35$ & $92.51 \pm 13.53$ \\
Minute 10 & $86.26 \pm 08.90$ & $111.40 \pm 0993$ \\
\hline
\end{tabular}

The diastolic pressure was decreased in group A, but increased in group B minute $0,1,3,5$, and 7 (Table $5)$.

Table 5. Diastolic pressure of groups A and B during and after tracheal intubation.

\begin{tabular}{lcc}
\hline Time & $\begin{array}{c}\text { Group A } \\
(\text { Mean } \pm \text { SD) }\end{array}$ & $\begin{array}{c}\text { Group B } \\
\text { (Mean } \pm \text { SD) }\end{array}$ \\
\hline Before induction & $77.77 \pm 10.22$ & $75.94 \pm 11.36$ \\
Minute 0 & $74.03 \pm 11.82$ & $94.17 \pm 10.70$ \\
Minute 1 & $71.66 \pm 09.58$ & $91.97 \pm 11.02$ \\
Minute 2 & $71.31 \pm 10.16$ & $72.80 \pm 10.74$ \\
Minute 3 & $69.03 \pm 13.18$ & $90.46 \pm 07.93$ \\
Minute 5 & $67.31 \pm 10.39$ & $93.80 \pm 10.28$ \\
Minute 7 & $65.74 \pm 90.71$ & $88.09 \pm 09.86$ \\
Minute 10 & $65.83 \pm 07.95$ & $74.20 \pm 10.38$ \\
\hline
\end{tabular}

Heart rate was significantly increased in group A from minute 0 to minute 7 and decreased in group B from minute 0 to minute 10 (Table 6).

Table 6. Heart rate per minute of groups $\mathrm{A}$ and $\mathrm{B}$ during and after tracheal intubation.

\begin{tabular}{lrr}
\hline Time & $\begin{array}{c}\text { Group A } \\
(\text { Mean } \pm \text { SD })\end{array}$ & $\begin{array}{c}\text { Group B } \\
(\text { Mean } \pm \text { SD) }\end{array}$ \\
\hline Before induction & $94.54 \pm 09.10$ & $90.83 \pm 08.10$ \\
Minute 0 & $111.32 \pm 14.12$ & $69.63 \pm 09.81$ \\
Minute 1 & $108.71 \pm 12.81$ & $86.21 \pm 08.16$ \\
Minute 2 & $104.26 \pm 11.09$ & $88.54 \pm 10.69$ \\
Minute 3 & $99.44 \pm 10.20$ & $85.54 \pm 08.95$ \\
Minute 5 & $94.74 \pm 09.59$ & $66.77 \pm 08.81$ \\
Minute 7 & $90.85 \pm 07.76$ & $85.29 \pm 07.88$ \\
Minute 10 & $87.59 \pm 07.84$ & $84.34 \pm 09.05$ \\
\hline
\end{tabular}

\section{DISCUSSION}

Anticholinergics (atropine), neuroleptics (droperidol) or narcotic-analgetics (pethidine), the traditional drugs in premedication, were not used in this study. Atropine in premedication remains controversial, ${ }^{14}$ because it has been incriminated in producing cardiac arrhythmias and visual difficulties, and in decreasing the tone of the lower esophageal sphincter. ${ }^{15}$ Atropine does not affect the hypertensive response to laryngoscopy and tracheal intubation, but did augment the tachycardia and increase the frequency of cardiac arrhythmias observed during intubation of the trachea. ${ }^{14,15}$ Droperidol or pethidine may attenuate the increase in arterial pressure following laryngoscopy and intubation $^{10}$ and was not used in this study. Diazepam (Valium, Roche) was used to produce sedation. It has only minimal effect on the cardiovascular system.

For many years the only route for administration of NTG was sublingual, but in recent years other routes, which include cutaneous, ${ }^{16,17}$ intravenous ${ }^{18,19,20}$ and intranasal, have gained acceptance. $^{21,22}$ NTG is rapidly absorbed into the vascular space when administered intranasally. Peak blood concentrations are reached at 2 minutes and decrease rapidly within 15 minutes. ${ }^{21}$ NTG can increase coronary blood flow, dilate large coronary vessels and increase oxygen delivery to the myocardium. This route may be of benefit to patients with ischaemic heart disease and impaired myocardial function. ${ }^{17,19}$ Intravenous NTG is noted for its rapid action, but preparation, standardization, and stabilization of such a solution is not without problems and can become expensive. Intranasal solution should be quickly and freshly prepared by crushing NTG tablets or opening NTG capsules in normal saline. This study chose a dose of $0.6 \mathrm{mg} / \mathrm{kg}$ body weight, a dose smaller than the $0.75 \mathrm{mg} / \mathrm{kg}$ used by Fassoulaki. ${ }^{22}$ The results were not much different. No significant increases or decreases in blood pressure were observed in both groups. Potential complications of the NTG include reversible hypotension and bradycardia, hypoxaemia due to increased pulmonary ventilation-perfusion mismatch, methemoglobinemia and headache was not found in this study.

\section{CONCLUSION}

The administration of NTG has been proven effective, safe, rapid, convenient, and economical in attenuating the hypertensive responses to laryngoscopy and tracheal intubation 


\section{Acknowledgment}

The author wishes to express his thanks to Dr Nunuk As ${ }^{*}$ at for her valuable help in preparation of this manuscript.

\section{REFERENCES}

1. Atkinson RS, Rushman GB, Alfred Lee J. Reflex circulatory responses to laryngoscopy and intubation. In: A Synopsis of Anesthesia. 1st PG Asian Economy Edition. Singapore $1987 ; 218$.

2. Wycoff CC. Endotracheal intubation: Effect on blood pressure and pulse rate. Anesthesiology 1960; 21: 153 - 8 .

3. Stoelting RK. Circulatory responses to laryngoscopy and tracheal intubation with or without prior oropharyngeal viscous lidocaine. Anesth Analg 1977; 56: 618 - 21.

4. Masson AHB. Pulmonary edema during or after surgery. Anesth Analg 1964; 43: 440 - 5.

5. Forbes AM, Dally FG. Acute hypertension during induction of anesthesia and endotracheal intubation in normotensive man. Br J Anesth 1970; 42: 618 - 22.

6. Delinger JK, Ellison $\mathrm{N}$ et al. Effects of intratracheal lidocaine on circulatory responses to tracheal intubation. Anesthesiology 1974; 41: 409 - 12.

7. Abou-Madi M, Keszler H, Yacoub O. A method for prevention of cardiovascular reactions to laryngoscopy and intubation. Canad Anesth Soc J 1975; 22: 316 - 29.

8. Ebert TJ, Mohanty PK, Kampine JP. Lidocaine attenuates efferent sympathetic response to stress in humans. J Cardiothor Vasc Anesth 1991; 5: 437 - 43.

9. Davies MJ, Cronin KD, Cowie RW. The prevention of hypertension at intubation. A controlled study of intravenous hydrallazine on patients undergoing intracranial surgery. Anesthesia 1981; 36: 147 - 52.
10. Currant J, Crowley M, O' Sullivan G et al. Droperidol and endotracheal intubation. Attenuation of pressure response to laryngoscopy and intubation. Anesthesia 1980; 35: 290-4.

11. Satwat AM, Fung DL, Bilton DC. The use of propranolol in rapid sequence anesthetic induction: Optimal time interval for pre treatment. Canad Anesth Soc J 1984; 31: 638 41.

12. Stoelting RK. Attenuation of blood pressure response to laryngoscopy and tracheal intubation with sodium nitroprusside. Anesth Analg 1979; 38: 116 - 9.

13 Puri GD, Batra YK. Effect of nifedipine on cardiovascular responses to laryngoscopy and intubation. $\mathrm{Br} \mathrm{J}$ Anesth 1988 ; 60: $579-81$.

14. Fassoulaki A, Kaniaris P. Does atropine premedication affect the cardiovascular response to laryngoscopy and intubation?. Br J Anesth 1982; 54: 1065 - 9.

15. Cotton BR, Smith G. Anticholinergic premedication and regurgitation. $\mathrm{Br} J$ Anesth $1981 ; 53: 445$ - 9 .

16. Taylor WR, Forrester JS, Magnusson $P$ et al. Hemodynamic effects of nitroglycerine ointment in congestive heart failure. Am J Cardiol 1976; 38: 469 - 73.

17. Wilkinson D, Anderson M, Gauntlett IS. Pain on injection of propofol: Modification by Nitroglycerine. Anesth Analg 1993; $77: 1139$ - 42

18. Kaplan JA, Dunbar RW, Jones EL. Nitroglycerine infusion during coronary -artery surgery $1976 ; 45: 14-21$

19. Loeb HS. Intravenous nitroglycerine. Chest 1980; 77: 374 5.

20. Hill AB, Antman EM, Green LH et al. Intravenous glycerine. A review of pharmacology, indications, therapeutic effects and complications. Chest 1981; 79: 69-75.

21. Hill $A B$, Bowley $C J$ et al. Intranasal administration of nitroglycerine. Anesthesiology 1981; 54: 346 - 8.

22. Fassoulaki A, Kaniaris $P$. Intranasal administration of nitroglycerine attenuates the pressor response to laryngoscope and incubation of the trachea. $\mathrm{Br}_{\mathrm{J}} \mathrm{J}$ Anesth 1983; 55: $49-52$. 